\title{
REPORT ON THE SEVENTY-FOURTH MEETING OF THE ASSOCIATION OF RESEARCH LIBRARIES HELD IN ATLANTIC CITY
}

\section{Program Meeting}

With the unsettling painted presence of the Playboy of the Gay Nineties-surrounded by opulent beauties wining and dining with a few male companions-as the backdrop, the Association of Research Libraries settled down to business as best it could in the Diamond Jim Brady Room of the Shelburne-Empress Hotel, Atlantic City, New Jersey, on Saturday, June 21, at 2:00 P.M. ARL President Douglas W. Bryant (Harvard) presided and introduced the representatives of the six libraries newly elected to membership-the University of Alberta, the University of California at Davis, Case Western Reserve University, Dartmouth College, the University of Massachusetts, and the New York State Library. This brings the total membership of ARL to eighty-five. Special guests and those other than the regular representatives of member libraries were also introduced.

The afternoon program was devoted to two reports. The first was on the University Library Management Study being conducted for ARL by Booz, Allen, and Hamilton (BAH) with the advice of a committee composed of Warren J. Haas (University of Pennsylvania), chairman, Mr. Bryant, Herman Fussler (University of Chicago), John McDonald (University of Connecticut), Robert Vosper (University of California at Los Angeles), Willard Boyd (Vice-President of the University of Iowa), Allan Cartter (Chancellor of New York University), Howard H. Johnson (President of Massachusetts Institute of Technology), and Richard Lyman (Vice-President of Stanford). The Council on Library Resources, Inc, made a grant for the first phase of the study, which was designed to identify problems of major significance in university library management that may possibly be solved by applying methods of scientific management and to establish priorities. The libraries of six universities-Connecticut, Cornell, Duke, Iowa, Pennsylvania, and University of California at Los Angeles-served as samples in the survey. University presidents and academic, business, and planning officers, as well as librarians, have been interviewed.

The American Council on Education is cosponsoring the study and named the non-librarian members. "Thus," said Mr. Haas, who presided over this presentation, "the result will not simply be librarians talking to themselves, but university administrators will also be involved." The progress report, presented by Douglas Metz and Tom Bertone of BAH, was,
Mr. Haas stressed, very preliminary.

Mr. Metz outlined some of the trends and challenges facing higher education, such as changing attitudes and expectations, the necessity for designing new programs that are actionoriented and meet social responsibilities, and the need to maintain a faculty and student body that constitute an outstanding community of scholars. He pointed to the increased enrollment ( 22 per cent "in the most recent" three years), new academic programs such as ethnic studies, a 74 per cent increase in master's and a 119 per cent increase in doctoral degrees conferred between 1949-50 and 196364, and an estimated 151 per cent increase in the number of faculty members between 194950 and 1967-68. Providing financial resources for such growth and change, particularly in private institutions, will be increasingly difficult. Organized research in universities has been "largely federally sponsored," but will this continue?

These trends have, of course, affected libraries. In less than a decade there has been a 50 per cent increase in the number of volumes in university libraries, from $176,721,000$ in 1959 to $265,000,000$ in $1965, \mathrm{Mr}$. Metz said. However, the number of volumes per student has declined from 46.5 in 1959 to 41.2 in 1965 . Over the same period, the number of "registered titles" has doubled, from 15,000 to 30,000 in the United States alone. Library costs have risen, for personnel, but especially for books, and financing of libraries has become increasingly complex. Demands upon university libraries, not only by the academic community, but by business, industry, and other nonacademic users have both increased and changed. Thus, larger library budgets are required. Because increased financing may not keep pace with these needs, efficient management is imperative. Effective planning, budgeting (especially Program Planning and Budgeting System), organization, staffing, and interinstitutional cooperation are essential.

But there are difficulties in comprehensive, systematic library planning. Often the universities themselves, although they have long-range plans, tend to operate on an ad hoc basis, and there are few effective systems for relating library planning to university planning. This, plus the limited time and scope university librarians and their staffs have for planning, leads to short-range, rather informal planning. Budget preparation is the best documented planning in libraries, but budgets are only for 

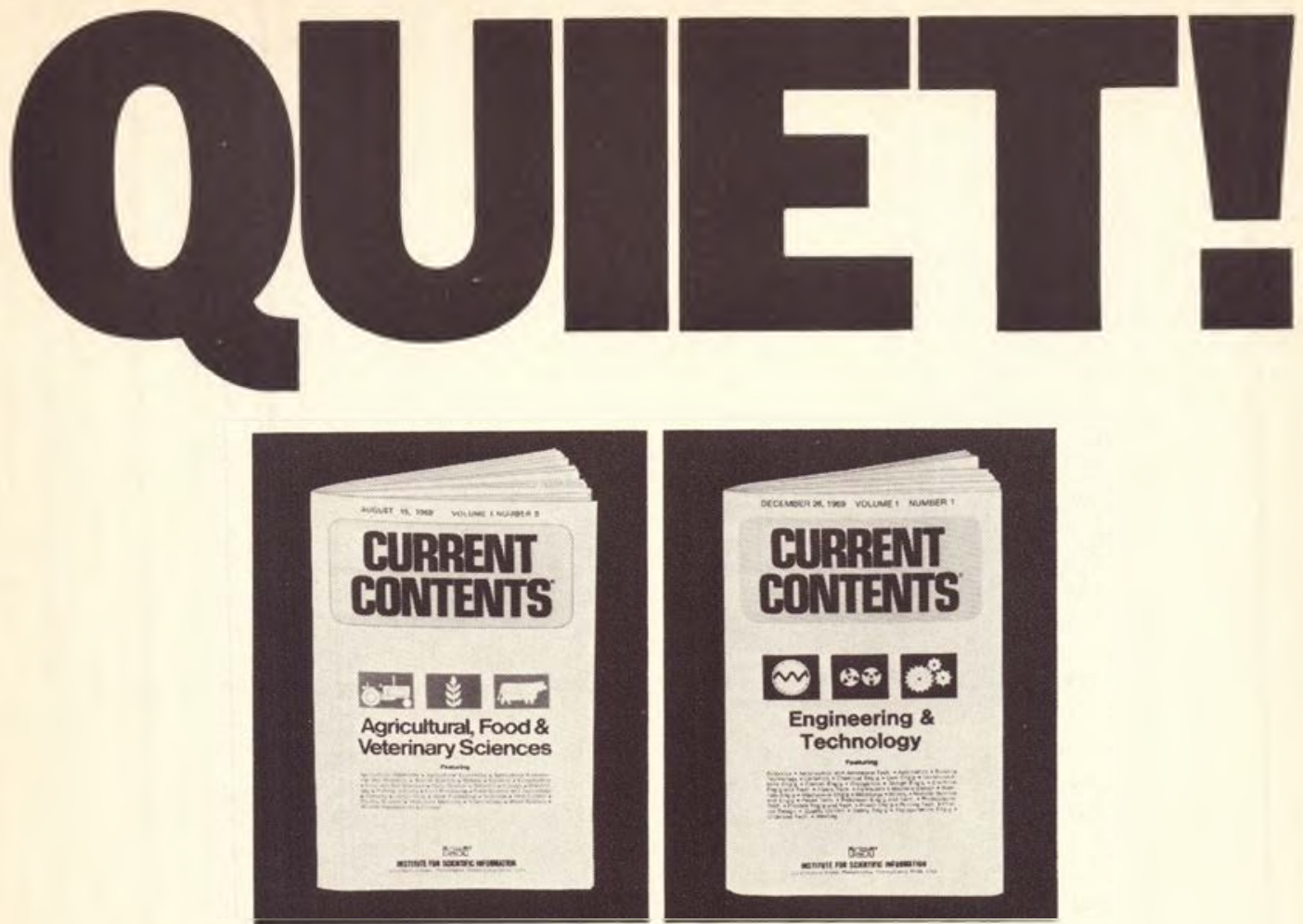

\section{Two new editions of Current Contents ${ }^{\circledR}$ are being born.}

The next two noises we make in your library will be titled: Current Contents-Agricultural, Food \& Veterinary Sciences and Current Contents-Engineering \& Technology. Their goal is the same as yours. To help make the library a more efficient, meaningful source of information.

These are the sixth and seventh Current Contents ${ }^{\circledR}$ offspring of the Institute for Scientific Information. (The others: Physical Sciences; Life Sciences; Chemical Sciences; Education; Behavioral, Social and Management Sciences.) If they enjoy as much success as the rest of the family has known, we'll be very proud parents, indeed.

These new editions of Current Contents, like the others, will be published weekly. They will each cover over 700 significant journals in their respective fields.

And they will be current. Many contents pages appear in advance of the publication's arrival in your library.

If your library doesn't use Current Contents, let us send you a free copy so you can evaluate its great worth for yourself.

If you are one of the many Librarians who already subscribe to other editions of Current Contents, let us send you free copies of these newest members of the family for your perusal.

After that we promise to be quiet... at least until we announce the arrival of the next edition of Current Contents.

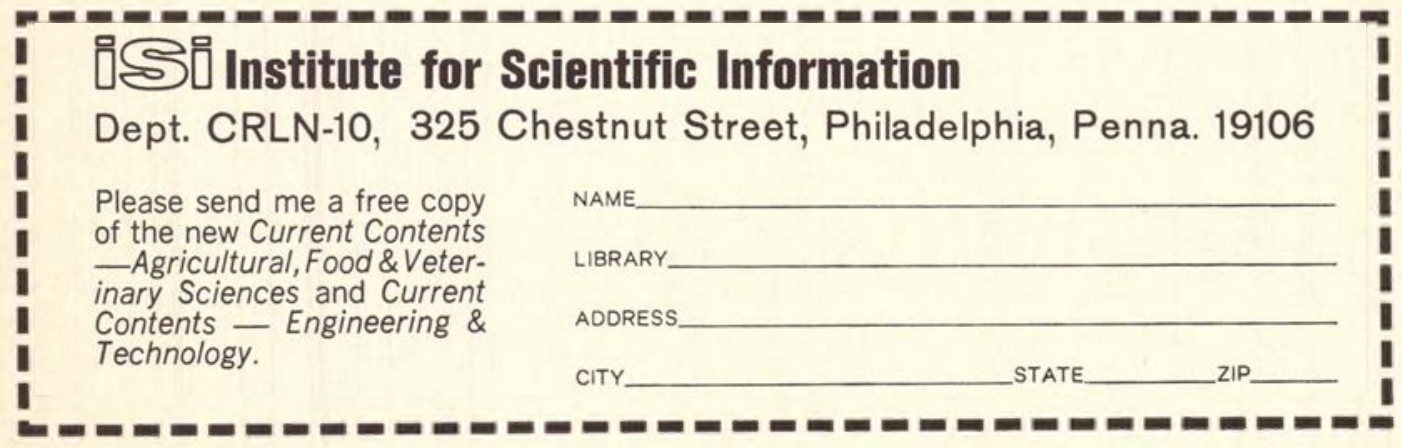




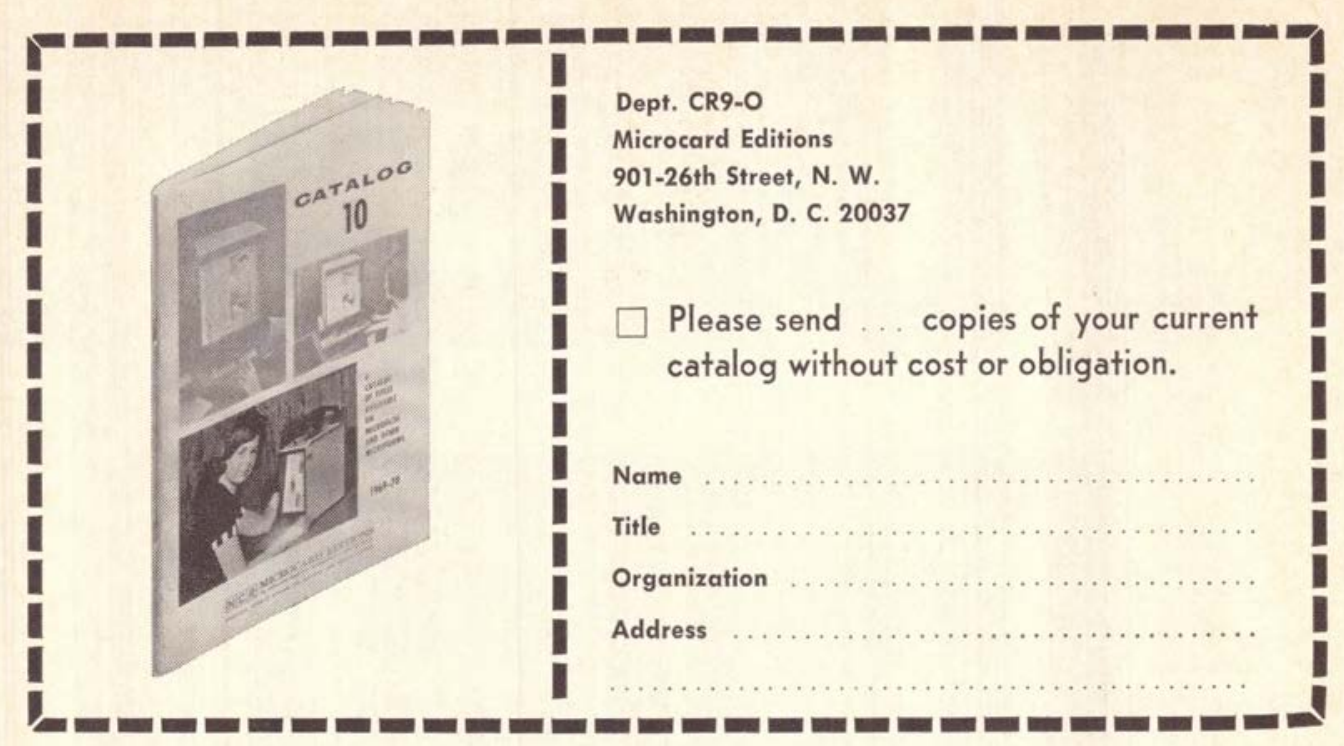

\section{NOW AVAILABLE ON MICROFICHE}

American Academy of Arts and Sciences. PROCEEDINGS

$$
\text { Vols. I-40 (1848-1905) }
$$

$\$ 120.00$

American Philosophical Society. PROCEEDINGS. Vols. I-53 (|838-19I4) _\$150.00

BRITISH CONTROVERSIALIST AND LITERARY MAGAZINE. $1850-72 \ldots \ldots \$ 120.00$

FRAZER'S MAGAZINE. Vols. I-I06 (1830-82)

$\$ 475.00$

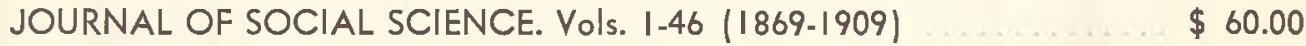

LIBRARY OF SOUTHERN LITERATURE. New Orleans, 1908-23 17 vols. _. \$ \$50.00

MUSICAL TIMES. Vols. I-52 (1844-1912)

$\$ 360.00$

NAPOLI GIORNALE DI MATEMATICHE. Vols. I-52 (|863-19|4) .... \$150.00

Washington, George. THE WRITINGS OF GEORGE WASHINGTON FROM THE ORIGINAL MANUSCRIPT SOURCES, I745-99. Washington, GPO, 193I-44. 39 Vols.

ZEITSCHRIFT FUR KRISTALLOGRAPHIE, MINERALOGIE, UND PETRO. GRAPHIE. Vol. I-I05 (1877-1944) (16 mm microfilm)

\section{$\mathbf{N} \mid \mathbf{C} \mathbf{R}$


one- or two-year periods. Furthermore, budget formats are "resource input rather than objective and program output oriented," Mr. Metz felt.

Mr. Bertone of BAH discussed problems of staffing. The most serious deficiency is lack of management training, he said. The preliminary study indicated that the status of librarians is uncertain; job classification structures do not generally reflect the highly skilled professional contributions made, but are weighted on the supervisory side; there is no inventory of the kinds of librarians that are needed; and there are recruiting difficulties. The high turnover of nonprofessional staff (students and faculty wives) is a serious problem for academic libraries.

Library organization, Mr. Bertone asserted, often results from unplanned response to evolving needs rather than to long-range planning and consideration of alternatives. In regard to operations, the role of the library in relation to the academic program and the university's commitment to the library have not been clearly defined, he said. Obviously, there is need of a strong library if the quality of the academic program is to be maintained and an outstand. ing faculty retained. There is a serious communications gap, which is a systems as well as an organization problem, the $\mathrm{BAH}$ study indicated.

Evaluations are difficult, for they tend only to reflect comparisons. But are "the best" libraries good, too good, or bad, Mr. Bertone asked, but found inadequate information for answering. Statistics are in terms of volumes held, circulation, etc., and they do not provide, he said, a data base for establishing relationships between university and library programs.

Operating policies are generally not codified as management guides, Mr. Bertone continued. Most systems used in university libraries are the traditional manual ones and the application of automatic data processing has been limited. While some university administrations are pressuring for the use of automation techniques in certain library operations, the library's needs for computer time "do not interface" with those of the university as a whole. Automation can improve library operations, but practical results will have to be demonstrated, and it is essential that systems and programs be transferable, and improvements can also be made in manual systems, Mr. Bertone felt.

Main libraries seem to have adequate facilities to meet current needs but have little room for expansion. Storage facilities at a distance from the campus are resisted by librarians and faculty alike, the study indicated. "An evolving solution seems to be the establishment of large decentralized libraries covering several major academic fields, e.g., the life sciences. An additional trend appears to be the provision of separate facilities for graduate and undergraduate students." More centralized services, such as LC's Shared Cataloging Program, and more cooperative and interinstitutional arrangements are needed, but the support of university administrations is necessary for the last-mentioned, and they seem to have low priority in planning.

Library financing is becoming more and more crucial and complex because of the multiple sources of funds. Grants, which are uneven and uncertain, pose major administrative problems and alternative funding sources must be sought, Mr. Bertone concluded.

Mr. Vosper, opening the panel discussion by the librarian members of the advisory committee, said that libraries face one of their most complex problems in determining how best to organize and utilize library staff. More professionalization is needed, he felt, and the subprofessional staff should be trained in order to release librarians for professional work. Too often, the professional staff members have an "academic outlook," whereas it is management skills and interests that are needed. They do, however, recognize the need for change in library management.

Herman Fussler, while strongly supporting recommendations for prudent management of libraries and library resources, felt that libraries were not always the guilty parties. There may be a serious mismatch between what universities expect of libraries and the resources that are available. In such cases, good management alone cannot solve the problems. He felt that ad hoc planning is one of the strengths of a university, even though it may adversely affect library planning. The communication gap between the library and the university administration may, he suggested, be intentional and fundamental; libraries in such cases could engage in long-range planning of a sophisticated nature that would prove to be useless. On the other hand, there is evidence that universities are recognizing the need for more careful planning; but there is also a need for recognition of the demands that are made on big libraries by other academic institutions. There is no formula for solving the centralization versus decentralization question, but it is a very important one; and interinstitutional relations constitute another fundamental problem with which universities are not yet able to cope, because, he said, they do not have the necessary mechanisms to link systems.

Mr. McDonald commented on the financial observations made, noting that many of the recommendations in the report would mean increased costs at a time when competition for funds is great. He noted particularly the difficulties of budget-making in some state institutions, where the levels through which a budget must pass are numerous and complicated.

Mr. Bryant observed that libraries are not in- 
dependent agencies but are largely guided and controlled by the programs of the parent institution. It is very important to stress this. $\mathrm{He}$ also pointed out that the sources of support for private universities have become increasingly complex, yet the base of support must be broadened even further.

Discussion from the floor brought out that one of the tools of modern management, Program and Performance Budgeting System, now a requirement in a number of universities, is itself costly; that the university librarian is fighting a battle for the faculty, for the university itself, and not for the library or the librarian; that library costs actually start with the faculty; that greater emphasis should be given in the report to interinstitutional arrangements, which can be very effective, especially in large metropolitan areas, but which must have the support of the administrators; that organizational "efficiency" should not be carried so far as to become "a straight-jacket"; that charges for library services, which had been suggested, would be comparable to supporting a fire department by leveling charges only against the people who had fires; that state universities may not be able to plan because of outside pressures and that in most universities there are political problems, which are not amenable to orderly planning or decision-making; and that an effort should be made to get student opinions and reactions as input to the study.

As the second major presentation of the afternoon, Burton W. Adkinson, Head of the Office of Science Information Service (OSIS), National Science Foundation, summarized his paper on "A Program for Support of University Centered Information Systems." The resources of his office are being concentrated, he said, on "developing information systems in basic disciplines which take advantage of the available technology." $\mathrm{He}$ stressed the limited funds available as contrasted with the resources of the Office of Education (OE) and the fact that OSIS tries not to duplicate OE-supported activities but to foster projects "in harmony with the broader program of OSIS on behalf of information systems development."

NSF has assisted libraries in four areas: (1) direct support of library operations, including help on construction, acquisition, and even salaries; (2) funding for curriculum development and training for professional development; (3) support of translation, abstracting, indexing, improvement of bibliographic services, and research into indexing theory and file organization; and (4) grants for the development of computerized systems for library operations. $\mathrm{He}$ pointed out that from 5 to 15 per cent of institutional grants must go to libraries.

Now, OSIS is emphasizing the development of "user-oriented, campus-based information services" in order to serve research scientists and students who will do the research of the future. These services will combine information retrieval, data reduction and analysis, and communications. The objective is to enable "a meaningful dialogue with a corpus of recorded knowledge." To obtain support for such activities, a university administration must meet the criteria of responsibility, of "representativeness" (responsiveness to requirements for information), and of "readiness" (technical competence). Systems oriented toward one or more of the scientific disciplines, interdiscipline and subdiscipline systems, and library systems and networks are the broad types of projects being funded. Mr. Adkinson cited a number of specific projects that illustrate OSIS' willingness to support improvement in library operations in the interest of the scientist-user. But, he concluded, the needs for total information transfer are just beginning to be explored, and ARL institutions can participate in and contribute to this effort.

During the discussion, Mr. Adkinson said that lack of adequate funding compelled OSIS to divide its resources among many competing projects. $\mathrm{He}$ noted again that $\mathrm{OE}$ had larger sums available, but a representative of $\mathrm{OE}$ said that it, too, was handicapped by inadequate funding. This, Mr. Skipper (Calif., Berkeley). observed wryly, reminded him of the little girl who was complaining about how poor her family was: "Daddy is poor, Mama is poor, and all the servants are poor." He inquired about the cost of user-oriented SDI and noted that the $\mathrm{BAH}$ report recommended that libraries be concerned with cost effectiveness, yet he found it difficult to relate this to the new types of information systems Mr. Adkinson described. These systems are expensive, Mr. Adkinson replied, but they are part of the university's, not the library's, budget.

Carl Jackson (Pennsylvania State University Library) observed that the profession is being rushed to a confrontation-the library versus the computer center. William Locke (MIT) mentioned that the real problems are software problems. The hardware is available, but computer tapes usually must be re-programmed. Mr. Fussler expressed the hope that the ARL could be helpful in developing an access system that would avoid waste; experimental work is necessary to identify issues, but methods could then be developed to provide appropriate means of access.

Replying to an inquiry from Porter Kellam (Georgia) about how to get science books-library support for projects that receive grantsMr. Adkinson noted that such support frequently is part of a larger application, sometimes separately identified but often not. If an application does not include a specific provision for the library, OSIS does not even see the proposal. To the suggestion that NSF should re- 


\section{A lot of colleges are buying library books when they should be buying libraries.}

When you order your books through the Xerox College Library Program, all you do to set up your library is unpack it.

We can send you the complete 2,000-volume Choice Opening Day Collection*, along with 4,500 enrichment titles (including Choice's Outstanding Academic Books and 500 out-of-print titles from the ALA bookIist, Books for College Libraries).

By ordering your library from us, you save yourself the time and trouble of going through hundreds of catalogs and booklists. And you save your college the expense of having thousands of orders typed up and mailed out.

Every book is listed in one annotated catalog. All of them-or as few as 100 -can be had with one order.

And every book comes fully cataloged and processed to LCistandards. If you're about to start a new college library-or add to an existing one-write for the free Xerox College Library Program Catalog.

Then, you'll be able to stop buying your library book by book. And start buying your books by the library.

\section{University Microfilms




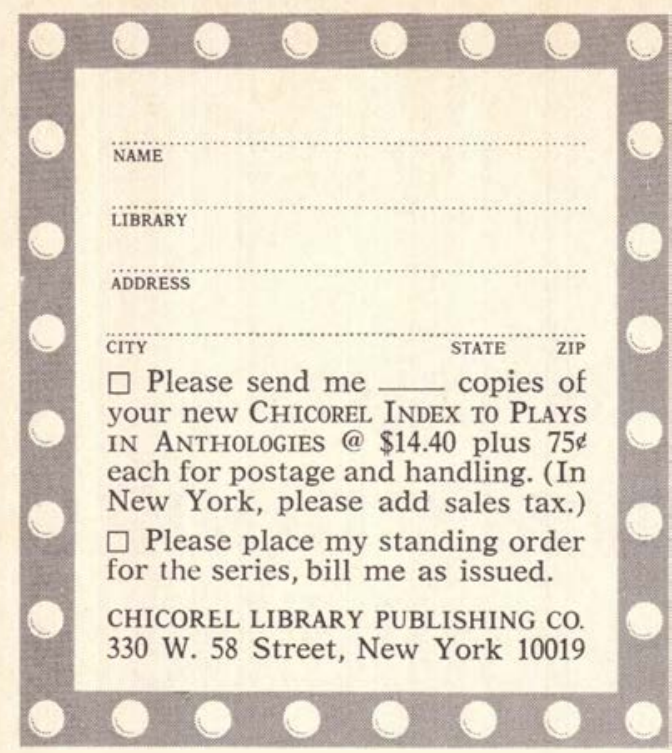

\section{This coupon opens a} new approach to plays with Chicorel

Index to Plays in Anthologies VOLUME 1

... indexes plays of all types, in English and in translation, Broadway to Off-OffBroadway, plays for children, texts, radio and $T V$, etc.

"Unique, quick, comprehensive, uncomplicated...", Celeste Ashley, Theatre Librarian, Stanford University. "Fills the void in play anthology indexing since 1962," Marvin Scilkin, Orange Public Library.

In one alphabetical arrangement full bibliographic information: entry by anthology title, editor, play title, playwright; entries give publisher, place, year, pages, LC number, price.

Descriptive note and contents.

No double-look-up, “. . . a much needed work ... compiled and organized by a librarian who knows problems of the profession ....", Richard Samuelson, Librarian, Somerset College, N.J.

Special pre-publication offer ... good until December 31, 1969. The price of admission only $\$ 14.40$ (Reg. $\$ 16.00$ ) in the U.S.A. \& Canada

CHICOREL LIBRARY PUBLISHING CO. 330 West 58 St. New York, N.Y. 10019 Telephone (212) 246-1743 quire that requests for grants be referred to the university librarian, Mr. Adkinson replied that NSF could not dictate; it can only say that support for library resources is an eligible item.

\section{Business Meeting}

President Bryant opened the business meeting at 7:45 P.M., introducing Thomas Buckman (Northwestern), chairman of the American Organizing Committee of the recent Japan-United States Library Conference on Libraries in Higher Education, who reported on the meeting (see pp. 293-96 of the LC Information Bulletin of June 5). The objective was to enable library leaders from the two highly industrialized countries to get acquainted, exchange views, and discuss areas of potential cooperation. Preparation for the conference brought together the three major university library organizations of Japan. They now propose to form an organization similar to the ARL to work on the kinds of problems with which ARL deals. Tatsuo Morito of Japan and Logan Wilson of the United States, the keynote speakers, both made the point that libraries can be the centers for higher education because they offer opportunities for independent work.

In presenting his report as president, Mr. Bryant noted that:

(1) ARL has accepted a grant from the National Agricultural Library to serve as the manager of a National Serials Pilot Project involving the three national libraries.

(2) An Interlibrary Loan Study Committee has been appointed, with Gordon Bechanan (Harvard), David Heron (Kansas), and Gordon Williams (Center for Research Libraries) as members, and Arthur McAnally (Oklahoma) as chairman.

(3) ARL's Board of Directors has authorized the formation of a Committee on Copying Manuscripts and Unpublished Materials, with Roy P. Basler (LC), William Bond (Harvard), William Cagle (Indiana), James Henderson (NYPL), and Oliver W. Holmes (National Historical Publications Commission) as members, and Verner W. Clapp (CLR) as chairman.

(4) ARL hopes to publish soon the Metcalf study of "Library Lighting" and the Ellsworth study of the "Economics of Book Storage."

(5) The American Council of Learned Societies has organized a Committee on Research Libraries, with John Blum (Yale), Frederick Burkhardt (ACLS), William Dix (Princeton), Carl Overhage (MIT), Gordon Ray (Guggenheim Foundation), George Winchester Stone, Jr. (NYU), and Robert Vosper (UCLA) as members and Douglas Bryant as chairman. It is hoped that this committee can relate both to the proposed National Commission on Libraries and Information Science and to university faculty members. 
(6) ARL's midwinter meeting will include not only a business and a program meetingpossibly discussions of staff participation in library decision-making and of automation as applied to university libraries-but also a visit to Northwestern University's new library building on Sunday morning, January 18.

Stephen McCarthy, in his report as ARL's executive director, also mentioned the grant from NAL for the National Serials Pilot Project. ARL's responsibility will be to produce a union list of the live scientific and technical serials held at each of the three national libraries and to obtain data needed by the management of these libraries to plan for effective utilization of their serial collections. Mr. McCarthy also reported that:

(1) The Board of Directors has authorized the appointment of an advisory committee to Raymund Zwemer (Federation of American Societies for Experimental Biology), who is making a study to develop quality control for the input of scientific information in computer systems.

(2) The first phase of the Microform Technology Project has been completed and an interim report will be distributed to members. A proposal to $\mathrm{OE}$ for a continuation of this project has been approved and a contract has been signed.
(3) The Center for Chinese Research Materials is expanding its reprinting and microfilming program.

(4) It is expected that an appointment to the position of Director of the Slavic Bibliographic and Documentation Center will soon be made.

Mr. Vosper, as chairman of the Federal Relations Committee, reported on the status of the proposed National Commission on Libraries and Information Sciences. The House bill provides for an independent commission, attached only for budget and housekeeping purposes to the Office of the Secretary of Health, Education and Welfare, while the Senate bill, which passed without opposition, places the commission in the Office of the Secretary. Commentary on the bill, Mr. Vosper said, seemed to protect the commission from being "sidetracked or downgraded." The effectiveness of the commission will depend on the ability and dedication of its membership; thus, he said, ARL should be prepared to present the names of potential appointees.

On advice of the Federal Relations Committee and on ARL's recommendation, certain changes in the guidelines for the College Library Resources Program (Title II-A of the Higher Education Act) were made. They gave weighted advantage for doctoral programs, for

\section{ACADEMIC UIBRARIES get more of the special services they need from THE BAKER \& TAYLOR CO. Oldest and Largest Book Wholesaler in the U.S.}

- 5,000,000 BOOKS IN 4 REgIONAL WAREHOUSES

- OVER 120,000 TITLES (SOON TO BE 200,000) FROM 1,500 PUBLISHERS

- BIGGEST INVENTORY OF UNIVERSITY PRESS BOOKS

\section{- MOST COMPLETE, FASTEST FIRST SHIPMENT SERVICE}

\section{New service programs from Baker \& Taylor}

University \& College Library New-Book Service. New-Book standing order program expressly designed to meet the needs of academic libraries. The new program enables libraries to receive, automatically, new books in subject areas they select. Baker \& Taylor's professional library staff chooses titles of interest to academic libraries from all books published in the English language, both in the U.S. and abroad. The program is supported by the largest stock of University Press, scholarly and trade titles available from any one source.

BÄTAB (Baker \& Taylor's Automated Buying) A newly-developed computerized book ordering system for libraries. This exclusive data processing system will enable librarians to automate any or all of a library's book ordering operations, from book acquisition through fund accounting and budget control.

For further information, write to the BAKER \& TAYLOR DIVISION nearest you.

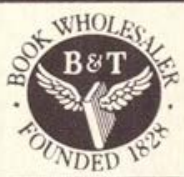

Send orders to your nearest BAKER \& TAYLOR DIVISION.

EASTERN DIVISION

SOMERVILLE, N.J. 08876

50 Kirby Avenue

Telephone: $201-722.8000$

N. Y. City Tel: 212-227-8470

MIDWEST \& SOUTHERN DIVISION

MOMENCE, ILL, 60954

Telephone: $815-472-2444$

Chicago Tel.: $312-346-4074$

WESTERN DIVISION

RENO, NEV. 89502

380 Edison Way

Telephone: 702-786-6700

INTERSTATE LIBRARY SERVICE CO.

(A subsidiary)

OKLAHOMA CITY, OKLA. 73118

4600 North Cooper

Telephone: 405-525.6561

NEW BOOKS INSPECTION CENTERS

LOS ANGELES, CAL.IF. 90036

5820 Wilshire Blvd.

Telephone: $213-938-2925$

HOUSTON, TEX. 77019

1701 West Gray Street

Telephone: 713-524-6411

BOSTON, MASS. (vicinity)

372 Main Street

Watertown, Mass. 02172

Telephone: $617-924-7522$ 


\section{Evan Farber}

-Librarian, Earlham College

Richmond, Indiana

- Chairman, College Libraries

Section, ACRL (1968-69)

- Author, CLASSIFIED LIST OF PERI-

ODICALS FOR THE COLLEGE LI-

BRARY, Faxon, 1957. (1970 edition now in preparation).

HERE'S HOW 474 SERIAL TITLES IN THE SCIENCES AND HUMANITIES WERE SELECTED FOR INCLUSION

All of the more than 1,000 cumulative indexes included in the collection are to serials which have been cited either in one or more recognized selection guides for libraries (including Farber's PERIODICALS FOR THE COLLEGE LIBRARY), or by one or both of the co-chairmen of the project's editorial board. The co-chairmen are: for the HUMANITIES GROUP. Pulitzer Prize-winning historian William Goetzmann, Chairman of the Department of History at the University of Texas, Austin; and, for the SCIENCE AND TECHNOLOGY GROUP, Joseph Shipman, director of the Linda Hall Library of Science and Technology, Kansas City, Missouri.

According to Mr. Shipman, "This collection offers a fast and inexpensive new approach to expanding the retrieval capacities of growing reference libraries, especially those that cannot immediately afford to build up long backfile runs of the basic scientific and technical journals."

The CUMULATIVE INDEXES TO SELECTED SERIALS which appear in our catalog are also listed in the August 1969 issue of ANNOUNCED REPRINTS and the 1969 editions of PUBLISHERS' TRADE LIST ANNUAL and BOOKS IN PRINT.

All 700 volumes are offered SEND TODAY FOR OUR FREE 40 PAGE Carrollton Press, 


\section{talks about serial backfiles}

and how to increase their accessibility

with

\section{INDEXES TO SELECTED SERIALS}

facsimile reprint collection from Carrollton Press

"Libraries which can't manage to have full runs of all the backfile serials they need, either in full size originals, reprints, or microforms, can utilize cumulative indexes for locating references as the basis for interlibrary loan requests. This identification process will become increasingly significant in the future as long distance inter-library facsimile transmission becomes more widely used.

"While the standard periodical indexes partially meet this need, large numbers of serials - even some of the most importantare not covered by them. There are also those that have only been covered recently because they were not recognized as significant in their earlier years. Moreover, many standard indexes did not include author entries, and only in a few cases do they index the contents as completely or in as great depth as do many of the journals' own cumulative indexes.
"The Carrollton Press reprint collection should prove particularly valuable in building up a library's serial reference capabilities at comparatively moderate cost, especially inasmuch as it is made up of cumulative indexes to those serial titles which have been selected by one or more authorities for inclusion in particular types of collections."

If your library's backfile serial holdings are:

—on microforms,

-in closed stacks,

-not in your department,

-incomplete, or even

-non-existent, get full size reprints of cumulaterendexes for open-shelf refer gains in refering. The result-maximum cost! ence capacity at

singly or in 46 modular subject sets for 1969 and 1970 deliveries. SUBJECT CATALOG OF CUMULATIVE INDEXES (NOW WITH A COMPLETE TITLE INDEX) 
service to non-university borrowers, for interlibrary loans, and for participation in certain national bibliographic and resource development enterprises. Although the funding outlook for next year may appear to make it an academic exercise, the committee, Mr. Vosper said, would appreciate advice in writing, quite soon, of other desirable modifications. He pointed out that ARL testified before the House Subcommittee on Appropriations for Labor, Health, Education, and Welfare on behalf of Title II funds in general.

In particular, ARL emphasized the importance of the National Program for Acquisitions and Cataloging (Title II-C), stressing that its advantages clearly extend to smaller libraries as well as to large libraries, "because the effectiveness of the national interlibrary lending network depends on the capacity of research libraries quickly to acquire and catalog foreign books." Testimony was also presented on behalf of the bill (H.R. 11223) to extend the Medical Library Assistance Act for another three years.

Chairman Vosper warned of the "potentially damaging impact on library programs of some of the "Tentative Decisions" of the House Ways and Means Committee in regard to foundations. These "Tentative Decisions" were issued officially on May 27 as a Committee Print. "While intending to correct some patent and even gross abuses of the tax exemption privileges granted private foundations," some of the proposed limitations would "severely cripple the responsible foundations upon whom education and libraries have so rightly depended for support over many decades," Mr. Vosper said. "One need only mention the Carnegie Corporation, the Council on Library Resources, and the American Council of Learned Societies to realize that the best friends of libraries are in potentially serious trouble, and further to realize that as beneficiaries we should be prepared to speak in their behalf." Also, proposed changes in the definition of a "private foundation" seem to indicate that ARL itself, and similar groups, could, in effect, become foundations, Mr. Vosper pointed out, or at least be subject to the same limitations, including taxation. There is "an even more clouded question concerning tentative changes in the tax treatment of charitable contributions, including "all gifts of works of art, collections of papers, and other forms of tangible personal property," Mr. Vosper noted, and he moved that the board be authorized to explore the matter fully, seek legal counsel, and take such steps as may seem appropriate and responsible. This was approved by unanimous vote of the membership.

John Lorenz (LC), chairman of the Foreign Newspaper Microfilm Committee, reported that CLR had made a grant of $\$ 13,000$ to ARL to enable the committee to make a study de- signed to develop a national program for the acquisition of foreign newspapers on microfilm. Norman Shaffer of LC is carrying out the study, which is in the fact-finding stage.

Robert Downs (Illinois), chairman of the Joint ACRL-ARL, Committee on University Library Standards, commented on the preliminary draft which reported summaries of data collected by his committee and which was distributed to the membership before the meeting. He sought advice on the desirability of presenting data (1) in terms of individual libraries and (2) on other professional libraries in addition to law and medicine. He also asked whether the data collected on the status of library staff members and on the relationship of the library to the central administration would be useful and should be published. One member of his committee, he said, felt that it was impossible to develop standards for university libraries; others suggested that the results should be called "averages" rather than "criteria," or that median figures rather than the mean figures should be used, since they would avoid the distortion caused by extreme numbers at each end of the scale. Discussion emphasized that all the data collected are valuable and should be published but that care should be exercised in presenting this material. Many felt that the words "standards" and "criteria" were inappropriate and misleading. Several suggested that the published material should include the first and third quartiles as well as the medians. If this were done, individual libraries could evaluate or rate themselves. It was pointed out, however, that the missions and objectives of institutions vary and that these variations could influence the use of the information. Clearly there was a desire to have access to the information collected, yet the consensus was that it must be so handled as to guard against misuse and misinterpretation. Mr. Downs stated that he would report ARL's reaction to his committee, which would then decide on what would be recommended to ARL and ACRL.

Gustave Harrer (Florida) announced the recent organization of the Association of Caribbean University and Research Libraries. This group hopes to develop cooperation among member libraries as one of the first steps in interinstitutional cooperation.

Several other committee reports, as well as the report of the Librarian of Congress summarizing major developments at LC in the first half of the calendar year 1969 were filed without summary or discussion.-Elizabeth $E$. Hamer, Library of Congress.

A limited number of reprints of this report, Appendix I to the Library of Congress Information Bulletin, August 7, 1969, are available from the Information Office, Library of Congress. 